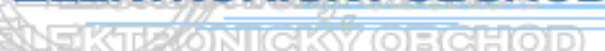

\title{
CERTIFIKOVANIE DIGITÁLNEJ GRAMOTNOSTI ZAMESTNANCOV VEREJNEJ SPRÁVY PROGRAMOM ECDL
}

\author{
Michaela Gajňáková*
}

\section{Úvod}

Počítače sa stali v priebehu niekol'kých rokov nevyhnutným pracovným nástrojom. Hoci donedávna sme ich mohli vnímat' pasívne či konzumne, dnes sa stali neoddelitel'nou súčast'ou každého $\mathrm{z}$ nás. Stretávame sa s nimi v škole, v bankách, na obecných a krajských úradoch, na súdoch.... Sme svedkami toho ako sa naša spoločnost' stáva informačnou spoločnost'ou, pričom rozhodujúcou sa stáva práca s informáciami. Počítače (PC) a informačno-komunikačné technológie (IKT) vstupujú do dennej praxe, pričom neustále narastá počet pracovných miest, ktoré vyžadujú ovládanie počítača. Schopnost' pracovat' s počítačom sa stáva $\mathrm{v}$ dnešnej dobe novou gramotnost'ou. Čo to vlastne je počítačová gramotnost'? Možno ju definovat' ako schopnost' človeka zvládnut' základné pravidlá práce s počítačom, obsluhou počítača a periférií, princípy ovládania základných druhov programov. [1] Klasické schopnosti preukážeme vysvedčením, výučným listom, diplomom, ale ako je to pri počítačovej gramotnosti? Odpoved' na túto otázku dáva medzinárodný koncept European Computer Driving Licence (ECDL).

\section{Koncept ECDL}

Koncept ECDL vznikol v roku 1996 na podnet The Council of European Professional Informatics Societes (CEPIS). Jedná sa o kvalifikačný program na získanie a preukázanie digitálnej gramotnosti (t.j. vedomostí a zručností potrebných pre efektívne využívanie IKT).

ECDL poskytuje prepracovaný, overený a odporúčaný kvalifikačný štandard základnej digitálnej gramotnosti. Je rozdelený do siedmych tematických celkov - modulov. Každý, kto úspešne absolvuje predpísané testy zo všetkých siedmych modulov, sa stáva držitel'om Certifikátu ECDL. Každý, kto úspešne absolvuje predpísané testy z l’ubovol’ných štyroch modulov, sa stáva držitel’om Certifikátu ECDL-Štart. Certifikát ECDL, ako medzinárodne uznávaný doklad počítačovej gramotnosti, vytvára jednotnú platformu pre preukazovanie a porovnávanie vedomostí z oblasti IKT, umožňuje mobilitu a širšie uplatnenie držitel'ov certifikátu ECDL na trhu práce, zvyšuje motiváciu zamestnancov k využívaniu moderných technológií. Vzhl'adom $\mathrm{k}$ tomu, že skúšky začínajú byt' uznávané i zo strany zamestnávatel'ov, predstavuje medzinárodne uznávaný Certifikát ECDL výhodu na trhu práce a to pri získavaní zamestnania, ale aj v rámci kariérneho rastu.

\footnotetext{
* Ing. Michaela Gajňáková, Žilinská univerzita v Žiline, Fakulta Prevádzky a ekonomiky dopravy a spojov, Katedra spojov, Univerzitná 1, 01026 Žilina,

tel.: + 415133144

e-mail: Michaela.Gajnakova@fpedas.uniza.sk
} 
Program ECDL je $\mathrm{v}$ súčasnosti zavedený a podporovaný prakticky vo všetkých krajinách Európskej únie (EÚ), pretože zapadá do Akčného plánu budovania informačnej spoločnosti $e$ Europe aj do Akčného plánu $e$ Europe+, ktorý prijalo aj Slovensko.

Koncept ECDL predstavuje široký potenciál využitia pre verejnú správu, kde sa môže stat' účinným nástrojom pre zvýšenie efektivity prevádzaných činností a tým i verejnej správy ako celku.

Vláda Slovenskej republiky sa vo svojom programovom vyhlásení zaviazala modernizovat' verejnú správu jej ekonomizáciou a informatizáciou. Zámerom je vybudovanie modernej verejnej správy, s ktorou budú občania spokojní, ktorá bude plnit' svoje úlohy efektívne, bude transparentná a minimálne zat'aží občanov, podnikatel'ov a ostatnú verejnost'.

Stále väčšie očakávania a nároky na vzdelanostnú úroveň zamestnancov vo verejnej správe v oblasti digitálnych technológií môžeme dosiahnut' len zmysluplným vzdelávaním a následnou certifikáciou.

\section{Piliere systému}

Základné piliere systému ECDL sú:

- Sylabus ECDL, ktorý definuje okruh základných vedomostí a zručností a štruktúruje ich do 7 modulov, ako aj sylaby d'alších častí programu ECDL.

- Manuálne bázy otázok a testov, ktoré sú sadami typizovaných otázok a úloh $\mathrm{k}$ témam určeným $\mathrm{v}$ základnom sylabe ECDL ako aj v d'alších sylaboch.

- Metodika overovania počítačovej gramotnosti: metodika testovania a vyhodnocovania, ktorá preukazuje zvládnutie predpísanej úrovne znalostí a zručností bez ohl'adu na platformu, použité softvérové nástroje a konkrétne národné prostredie.

- Metodika administratívy a zabezpečovania kvality testovania.

- Súbor chránených názvov, ich skratiek a logo ECDL.

- Medzinárodne rešpektovaný súbor dokladov ECDL. [2]

\section{Dôvody zavedenia certifikovania digitálnej gramotnosti}

V prebiehajúcom prerode našej spoločnosti na informačnú spoločnost' sa rozhodujúcou technológiou stáva práca s informáciami t.j. ich zber, spracovávanie, uchovávanie a šírenie. Prudký rozvoj informačných a komunikačných technológií a ich uplatnenie prakticky vo všetkých oblastiach života spoločnosti vyvoláva potrebu zabezpečit' možnosti pre celoživotné vzdelávanie a certifikáciu širokého okruhu zamestnancov rôznych (neinformatických) profesií tak, aby boli schopní tieto technológie pri svojej práci tvorivo využívat'. Pri systematickom zavádzaní vzdelávacích programov sa musí klást' dôraz v prvom rade na kvalitu vzdelávania a jeho uplatnenie pri profesijnom raste zamestnancov.

Dnes prechádzame do znalostnej fázy rozvoja civilizácie a teda znalosti sa považujú za hlavnú hodnotu každej organizácie. Pri vel'kom množstve potrebných vedomostí a ich pomerne častej zmene, základnými prostriedkami vytvárania a udržiavania „znalostnej infraštruktúry“ organizácie sú informačné technológie. Pre ich správne využívanie musia byt' zamestnanci $\mathrm{v}$ tejto oblasti vzdelaní a vzdelávaní. Zamestnávatel' má mat' schopnost' a možnost' preverovania ich vedomostí jednotným certifikovaným spôsobom, aby mal istotu, že prostriedky do IT i vzdelávania v tejto oblasti sú správne a efektívne využívané. [3] 
Na certifikáciu úradníkov bolo zvolené European Computer Driving Licence najmä z týchto dôvodov:

1. Európskej komisii odporučila Pracovná skupina pre zamestnanost' a sociálny rozmer informačnej spoločnosti (ESDIS) svojim záverom, týkajúcim sa zavedenia Európskeho diplomu pre základné znalosti v oblasti informačno-komunikačných technológií, že ECDL má byt' akceptovaný ako celoeurópska akreditačná schéma v oblasti IKT, naplńajúc tak ciele Akčného plánu budovania informačnej spoločnosti eEurope 2002.

2. Kvalifikačný program ECDL je založený na ECDL štandarde, t.j. na jednotnom schválenom okruhu základných vedomostí a zručností potrebných pre efektívne používanie IKT a na predpísanom spôsobe preukázania vedomostí a zručností.

3. Program ECDL je $\mathrm{v}$ súčasnosti zavedený a podporovaný prakticky vo všetkých krajinách EÚ, pretože zapadá do akčných plánov budovania informačnej spoločnosti, ktoré prijalo aj Slovensko.

4. V súlade so schválenou "Stratégiou informatizácie spoločnosti v SR" deklaruje vláda SR ako jeden z prioritných ciel'ov vytvárat' podmienky pre rozvoj všetkých foriem vzdelávania, vrátane celoživotného vzdelávania, ktoré umožní začlenenie SR a jej občanov do globálnej informačnej spoločnosti.

5. Certifikát ECDL deklaruje, že jeho držitel' úspešne absolvoval medzinárodne stanovené kvalifikačné testy, $v$ ktorých preukázal, že rozumie základným pojmom z oblasti IKT a spĺn̆a minimálne znalostné kritériá pre prácu $\mathrm{s}$ počítačom a počítačovými aplikáciami. ECDL, ako medzinárodne uznávaný certifikát, vytvára jednotnú platformu pre preukazovanie a porovnávanie vedomostí z oblasti IKT, umožňuje mobilitu a širšie uplatnenie držitel'ov certifikátu ECDL na trhu práce, zvyšuje motiváciu zamestnancov na využívanie moderných technológií a $\mathrm{v}$ konečnom dôsledku vytvára aj tlak na efektívne a meratel'né zhodnocovanie investícií do oblasti informačno-komunikačných technológií. [4]

\section{Koncept ECDL pre verejnú správu}

Omnoho širší potenciál využitia však predstavuje koncept ECDL pre verejnú správu, kde sa môže stat' účinným nástrojom pre zvýšenie efektivity prevádzaných činností a tým i verejnej správy ako celku. Úlohu, ktorú môže ECDL zohrat' pri modernizácií verejnej správy si už mnohé európske krajiny uvedomili a napr. v Belgicku získa zamestnanec po zložení predpísaných skúšok príplatok k platu.

V d’alších štátoch Európy sú potom štátni zamestnanci ku zloženiu skúšok motivovaní ak je koncept zahrnutý do strategických materiálov. Ako príklady možno uviest' Estónsko, ktorého vláda už v roku 2001 schválila akčný plán, ktorý ukladá všetkým zamestnancom verejnej správy zloženie ECDL testov.

Podobnú úpravu ako Estónsko má v uznesení č. 1035/1999 i Mad’arsko, kde by skúšku ECDL mali zložit' štátni zamestnanci vybraných profesií. Vd’aka akčnému plánu eNorway vyhláseného Ministerstvom priemyslu a obchodu Nórska získalo možnost' zložit' skúšku ECDL v tejto severskej krajine viac než 92000 zamestnancov.

V Írsku je koncept ECDL zavedený na všetkých úradoch miestnej štátnej správy, väčšine ministerstiev a štátnych agentúr. Len do roku 1998 tak v materskej krajine konceptu ECDL absolvovalo túto medzinárodne uznávanú skúšku cez 40000 zamestnancov. Povinnost' zloženia skúšky ECDL Štart mali do konca roku 2002 i všetci zamestnanci švédskeho ministerstva obrany. [5] 
Ministerstvo vnútra Českej republiky (ČR) vydalo na základe uznesenia vlády s platnost’ou od 31. marca 2006 Vestník (čiastka 32), ktorým sa stanovuje kvalifikačná požiadavka pre vybrané systemizované pracovné miesta na Ministerstve vnútra. Súčasní aj budúci zamestnanci na systemizovaných pracovných miestach musí splnit' požiadavku certifikácie počítačovej gramotnosti najneskôr do dvoch rokov. Náklady spojené $\mathrm{s}$ absolvovaním ECDL testovania $\mathrm{v}$ uvedenom rozsahu vrátane jedného možného opravného testu sú hradené zamestnávatel'om, náklady na prípadný druhý a každý d’alší opravný test sú platené zamestnancom. [6]

\section{ECDL vo verejnej správe v Slovenskej republike}

Vzhl'adom na narastajúcu akceptáciu programu ECDL vo svete a aj vo verejnej správe viacerých štátov, ako aj s ohl'adom na pozitívne výsledky pilotného projektu, sa kvalifikačný program ECDL na Slovensku stal súčast'ou viacerých koncepčných štátnych materiálov.

$\mathrm{V}$ akčných plánoch pre implementáciu Lisabonskej stratégie s názvom Stratégia konkurencieschopnosti Slovenska do roku 2010, ktoré schválila vláda SR 13.07.2005, sú v oblasti pre vedu a techniku uvedené úlohy, ktorých ciel'om je efektívna elektronizácia verejnej správy, t.j. zabezpečenie kvalitného vybavenia vo verejnej správe informačnokomunikačnými technológiami a zvýšenie informatickej gramotnosti pracovníkov v štátnej správe. Časová postupnost' krokov bola určená tak, aby sa dosiahli tieto ciele:

- do 31. 08. 2006 minimálne 8000 štátnych zamestnancov bude mat' certifikát ECDL Štart

- do 31. 12. 2008 všetci štátni zamestnanci budú mat' certifikát ECDL - Štart. [2]

Povinnost' mat' Certifikát ECDL (resp. Certifikát ECDL Štart) pre zamestnancov verejnej správy bola súčast'ou zákona 231/2006 Z. z. z 15. marca 2006, ktorým sa mení a dopíňa zákon č. 312/2001 Z.z. (konkrétne §14, ods.1, písm.k) o štátnej službe, ktorý schválila Národná rada SR a to v období od 01.06.2006. Ked’že Vláda SR túto povinnost' $\mathrm{k}$ 31.12.2006 zrušila, zamestnanci verejnej správy nemusia získat' Certifikát ECDL povinne do konca roku 2008. [7]

Zamestnávatelia vo verejnej správe musia byt' schopní preverovat' vedomostí pracovníkov jednotným certifikovaným spôsobom, aby sme mali istotu, že investície do IT i vzdelávania $\mathrm{v}$ tejto oblasti sú správne a efektívne využívané

Hoci Vláda SR k 31.12.2006 zrušila povinnost' vlastnit' Certifikát ECDL Štart, V súčasnosti však niektoré organizácie verejnej správy (napr. ministerstva, krajské úrady, samosprávne kraje, súdy, úrady práce, atd'.) nad’alej požadujú od svojich zamestnancov absolvovanie testov ECDL ako súčast' svojich vzdelávacích programov.

Väčšina týchto organizácií umožňuje svojim zamestnancom získat' Certifikát ECDL Štart v rámci projektov, ktoré sú hradené z Európskeho sociálneho fondu. Zamestnanci, ktorí sa rozhodli doplnit' si počet skúšok, aby mohli získat' Certifikát ECDL sú už ale väčšinou samoplatcovia.

Testy ECDL je možné vykonávat' len v akreditovaných testovacích centrách, ktoré sa nachádzajú vo všetkých krajoch SR. Zamestnanci majú možnost' pred samotným testovaním absolvovat' odborné školenia vybraných modulov, bud' prezenčnou alebo dištančnou formou. Pri prezenčnom vzdelávaní prebieha školenie od 1-5 dní. Účastníci dištančného vzdelávania ECDL sa môžu zúčastnit' na konzultáciách (v rozsahu 4 hodín) k vybraným modulom ECDL. Samozrejme absolvovat' test môžu aj bez odborného školenia. [8] 


\section{Záver}

Počítače a informačno-komunikačné technológie sa stali neoddelitel'nou súčast'ou dennodennej práce zamestnancov verejnej správy. Schopnost' pracovat' s počítačom sa teda stala novou gramotnost'ou, ktorú môžeme preukázat' pomocou programu European Computer Driving Licence. ECDL predstavuje široký potenciál využitia aj pre verejnú správu, kde sa môže stat' vynikajúcim nástrojom pre zvyšovanie efektivity rôznych činností.

Stále väčšie očakávania a nároky na vzdelanostnú úroveň zamestnancov vo verejnej správe voblasti digitálnych technológií môžeme dosiahnut' len neustálym vzdelávaním a následnou certifikáciou. Treba si uvedomit', že postupne dochádza k elektronizácii verejnej správy, ktorá si vyžaduje, aby zamestnanci verejnej správy zvládali prácu s IKT! Preto musí byt' snahou zamestnávatel'ov, aby motivovali zamestnancov k vzdelávaniu $\mathrm{v}$ oblasti počítačovej gramotnosti. Jedným z riešení je, aby vzdelávanie bolo rozdelené do dvoch častí - prezenčného a e-learningového vzdelávania. Hlavne e-learningové vzdelávanie zamestnancov verejnej správy má vel'kú budúcnost'. Vd'aka nemu môže verejná správa ušetrit' vel'ké množstvo finančných prostriedkov.

Hoci Vláda SR zrušila povinnost', aby každý zamestnanec verejnej správy vlastnil Certifikát ECDL Štart, snahou Odboru implementácie Operačného programu Informatizácia spoločnosti ako súčast' Sekcie informatizácie spoločnosti Ministerstva financií SR je, aby tento zákon opät' nadobudol platnost'.

$\mathrm{Na}$ záver možno dodat', že práca s počítačom má vlastne rovnaký charakter ako riadenie auta. Nestačí ju zvládnut' len teoreticky, ale dôležité je vediet' riešit' bežné životné situácie. Pri prijímaní do zamestnania či pri preverovaní činnosti, ktorá predpokladá schopnost' pracovat' s počítačom, je vhodné sa presvedčit', či je zamestnanec na požadovanú prácu pripravený. Zhodnotenie stavu ukázalo, že program ECDL si postupne buduje pevné miesto vo vzdelávaní v oblasti počítačovej gramotnosti.

\section{Literatúra}

[1] FRANCŮ, M.: Jak zvládnout testy ECDL. Computer Press, a.s., Brno, 2007. ISBN 97880-251-1485-8.

[2] Slovakia. [online]. [s.a.]. [Citované 2008-01-23]. Dostupné na: $<\mathrm{http}$ //www.ecdl.com/countries/index.jsp?1nID=103\&pID=167\&nID=229>.

[3] Národný projekt Vzdelávanie zamestnancov vo verejnej správe zamerané na získavanie digitálnej gramotnosti. [online]. [s.a.]. [Citované 2008-02-14]. Dostupné na: $<$ http://www.finance.gov.sk/Default.aspx?CatID $=5815>$.

[4] MANDÍKOVÁ K.< katarina.mandikova@mfsr.sk>. 2008-03-03. Vlastný materiál [Email adresátovi Michaela Gajňákovej<michalka218@gmail.com>].

[5] PRŮŠA, J.: Mezinárodní certifikace počítačové gramotnosti [Diplomová práca]. Vysoká škola veřejné správy a mezinárodních vztahů, Praha, 2007.

[6] Obchodní aktuality. [online]. [s.a.]. [Citované 2008-03-25]. Dostupné na: $<$ http://www.ecdl.cz/obchodni_aktuality.php $>$

[7] SCHEBER A. <anton.scheber@softec.sk>. 2008-03-07. ECDL [E-mail adresátovi Michaela Gajňákovej<michalka218@gmail.com>].

[8] MANDÍKOVÁ K.< katarina.mandikova@mfsr.sk>. 2008-03-03. Vlastný materiál [Email adresátovi Michaela Gajňákovej<michalka218@gmail.com>]. 